\title{
A Genomic Study on the Cultivable and Nerve Invading Mycobacterium HI-75 after the Recovery 3 Months of the Inoculation to Nude Mice.
}

\author{
Tetsuo Sakai1)*, Hamit Sidik²), Eiichi Matsuo ${ }^{2)}$ \\ Ruriko Hayakawa ${ }^{1)}$ and Akira Wakizaka ${ }^{1)}$ \\ 1)Department of Biochemistry and Molecular Biology, and \\ 2)Department of Pathology Kyorin University School of Medicine, Tokyo, Japan
}

〔Received 5 November 1997/ Accepted 15 December 1997〕

Key words; Mycobacterium HI-75; DNA sequence; $16 \mathrm{~S}$ ribosomal RNA;

Leprosy; Mycobacterium scrofulaceum

The sequence of the polymerase chain reaction (PCR) product of $16 \mathrm{~S}$ ribosomal RNA (1uS rRNA) of the leproma-derived and cultivable Mycobacterium HI-75 (M. HI-75) which was obtained from the infected regions of inoculated mice, was examined and compared with that of the cultured bacteria by the direct sequencing techniques. The sequence was completely consistent with the cultured bacilli in the comparable 837 bases of $16 \mathrm{~S}$ rRNA. The mycobacterium examined in this study was originally isolated as M. leprae (ML) by Skinsnes, et al. in 1975 from leproma of a lepromatous type Hansen's disease patient and therefore named as Mycobacterium leprae HI-75 by them, and was maintained from 1984 using either Ogawa's or Sauton's media in the beginning and Ogawa's medium enriched with glucronic acid and N-acetyl-D- glucosamine recently. Sasaki and Hamit reported the nerve invasion and the growth of the inoculated bacilli either to the nude mice or the ${ }^{131}$ treated immunocompromised Swiss mice. We previously reported that cultured HI-75 was most similar to $M$. scrofulaceum by the direct sequencing of the gene of $16 \mathrm{~S}$ rRNA. The $16 \mathrm{~S}$ rRNA obtained from the mouse tissue in the present study indicated that M. HI-75 would be a variant of M. scrofulaceum possessing an ability to invade into peripheral nerve. The results suggest that the $H I-75$ strain claims a nature as a pathogen to develop a leproma-like lesion.

Our previous analytical results of the sequences of $16 \mathrm{~S}$ ribosomal RNA (16S rRNA) of Mycobacterium HI-75 (M. HI-75), which was obtained from a Hansen's disease patient and was

"Corresponding author :

Department of Biochemistry and Molecular Biology, Kyorin University School of Medicine, 6-20-2

Shinkawa, Mitaka, Tokyo 181, Japan

Fax:+81-422-407281 cultured in the laboratory ${ }^{1)}$, showed that the strain was most similar to $M$. scrofulaceum ${ }^{2)}$. In experimental models $M$. HI-75 invaded into peripheral nerve and caused neuropathy ${ }^{3}{ }^{4}$ ). The aim of the present study is to analyze the genomic sequences of the bacillus which has been inoculated to mice and recovered from legional tissue of the mice in comparison with the sequences obtained from the cultured ones. 


\section{MATERIALS AND METHODS}

Bacterial strain and tissue preparation. The leproma-derived and cultivable $M$. HI-75 have been maintained by cultivation utilizing Ogawa's medium enriched with glucuronic acid and $\mathrm{N}$ acetyl-D-glucosamine. The bacillus was inoculated through the subcutaneous injection in the cheeks of mice ( $8 \mathrm{wks}, \mathrm{BALB} / \mathrm{cA}$ euthymic $(+/+)$, female) and maintained for 3 months. Mouse cheek skin was recovered from infected legions and examined immediately.

Analytical procedures. 10 to $20 \mathrm{mg}$ of the mouse tissue was homogenized in $100 \mu \mathrm{l}$ of buffer (10mM Tris-HCl, pH7.6, 10mM EDTA, pH8.0). After incubation of the homogenate with $100 \mu \mathrm{l}$ of lysozyme $(10 \mathrm{mg} / \mathrm{ml})$ at $37^{\circ} \mathrm{C}$ for 1 hour, the mixture was vigorously mixed with glass beads for one minute to disintegrate the materials. The DNA was extracted with SepaGene ${ }^{\text {TM }}$ (Sanko Junyaku, Tokyo, Japan) according to the manufacturer's procedure. Then the DNA was suspended in $100 \mu \mathrm{l}$ of TE buffer (10mM TrisHCl, pH7.h, lmM EDTA, pH8.0). Polymerase chain reaction mixture contained $5 \mu \mathrm{l}$ of $25 \mathrm{mM} \mathrm{MgCl}_{2}$, $10 \mu \mathrm{l}$ of $10 \mathrm{X}$ PCR buffer, $8 \mu \mathrm{l}$ of $2.5 \mathrm{mM}$ each dNTPs, $61.5 \mu \mathrm{l}$ of autoclaved ultra-pure water, $0.5 \mu \mathrm{l}$ of Taq DNA polymerase (2.5 unit), $5 \mu \mathrm{l}$ of each sense and antisense primers (20 p mole), and $5 \mu$ lof DNA solution mentioned above for the template. The reaction was primed by a template melting step at $94^{\circ} \mathrm{C}$ for $5 \mathrm{~min}$, followed by 35 cycles of the serial temperature changes consisting of $94^{\circ} \mathrm{C}$ for $30 \mathrm{sec}, 55^{\circ} \mathrm{C}$ for $1 \mathrm{~min}$ and $72^{\circ} \mathrm{C}$ for $1 \mathrm{~min}$ using the apparatus (Perkin Elmer, Norwalk, USA). Thus obtained PCR product was sequenced by the use of an AutoLaod ${ }^{\mathrm{TM}}$ SolidPhaseSequencing kit (Pharmacia Biotec, Tokyo, Japan), biotinylated primers and fluorescein (FITC) conjugated primers ${ }^{2)}$ on a Pharmacia model A.L.F. DNA Sequencer (Pharmacia Biotec, Uppsala, Sweden). The both sequence of sense and antisense strand was analyzed and compared with each others to confirm the accuracy. The sequences of $16 \mathrm{~S}$ rRNA from 8 th to 341 st, 518 th to 928 th and 1170 th to 1540 bases were examined using the gene data base issued from GenBank, published data by Rogall et al. and the results of the previous report in this journal ${ }^{2)}{ }^{5}$ ) 6) 7 )

\section{RESULTS}

Histopathology of the lesion of inoculated mice showed the accumulation of macrophages emcompassing peripheral nerves, marked infiltration of the mycobacteria and the invasion of the bacilli in the small branches of the peripheral nerves 3 months after inoculation (Figure.1).

The sequences from 8-341st, 518-928th and 1170-1540th base regions of 16S rRNA referred to those of $E$. coli was analyzed. The sequences of M. HI-75 obtained from legional tissue of the inoculated mice were completely consistent with those of the cultured M. HI-75 in detectable 837 bases as previously described. These regions of $16 \mathrm{~S}$ rRNA contain well conserved, bacteria specific and variable species-specific regions.

\section{DISCUSSION}

The applicability of $16 \mathrm{~S}$ rRNA sequences for bacterial classification is well accepted ${ }^{8)}{ }^{91} .16 \mathrm{~S}$ rRNA gene consists of genomically highly conserved primary sequences and species-specific nine variable regions. We examined the V1, V2, $\mathrm{V} 4, \mathrm{~V} 5, \mathrm{~V} 8$ and V9 regions of $16 \mathrm{~S}$ rRNA. The sequences were completely homologous to those of $16 \mathrm{~S}$ rRNA of M. HI-75, which is 5 out of 837 bases $(0.6 \%)$ deviated from those of $M$. scrofulaceum. M. leprae differed from M. HI-75 in 32 bases $(3.8 \%)$ in the $16 \mathrm{~S}$ rRNA sequence. In previous report we concluded that the lepromaderived and cultivable $M$. $H I-75$ was a variant of 
Fig.1. Acid-fast stains of mouse cheek skin tissue 3 months after inoculation of M. HI-75 (X400). An arrow indicates the bacilli in a small branch of the peripheral nerve leaving the larger one intact.

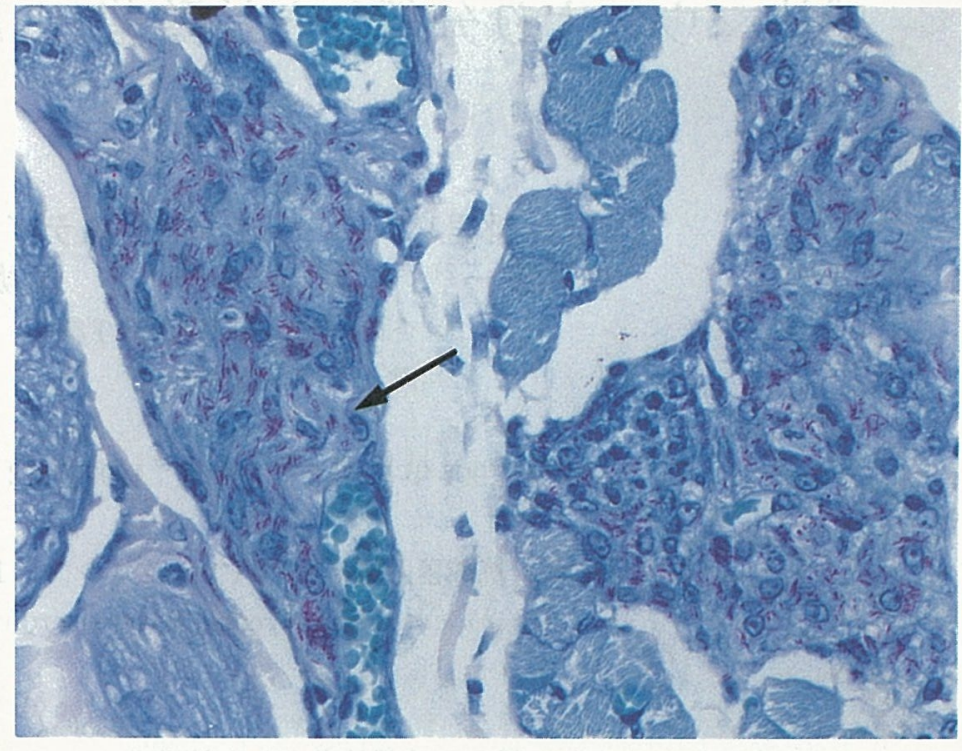

M. scrofulaceum ${ }^{2)}$. Present study also suggested that the same strain of M. HI-75 could invade into the living mouse tissue and stayed there developing lesional foci without any change in the genomic sequence of the examined ribosomal RNA gene. This would be one of the proof that $M$. scrofulaceum possibly possesses a pathogenetic activity in peripheral nerve causing like that of $M$. leprae.

\section{REFERENCES}

1. Skinsnes OK, Matsuo E, Chang PHC, Anderson $\mathrm{B}$. In vitro cultivation of leprosy bacilli on hyaluronic acid based medium. 1. preliminary report. Int J Lepr 43:193-203 (1975).

2. Sakai T, Matsuo E, Wakizaka A. A genomic study of the leproma-derived and cultivable Mycobacterium HI-75. The direct sequencing of PCR product of $16 \mathrm{~S}$ ribosomal RNA. Jpn J Lepr 65:180-185 (1996).

3 . Sasaki K. On the mice footpads inoculation of a leproma-derived and cultivable mycobacterium. The Annual Report of National Tama Research Institute. 35th Issue, National Tama Research Institute, Tokyo. 1985 (in Japanese).
4. Hamit S. An experimental nerve lesion simulating leprous neuropathy produced in the nude mice by the inoculation of a lepromaderived and cultivable Mycobacterium HI75. Jpn J Lepr 65:174-179 (1996).

5 . Edwards U, Rogall T, Bloker H, Emde M. Bottger EC. Isolation and direct complete nucleotide determination of entire genes. Characterization of a gene coding for $16 \mathrm{~S}$ ribosomal RNA. Nucl Acids Res 17:7843-7853 (1989).

6 . Rogall T, Flohr T, Bottger EC. Differentiation of Mycobacterium species by direct sequencing of amplified DNA. J Gen Microbiol 136:1915-1920 (1990).

7. Rogall T, Wolters J, Flohr T, Bottger EC. Towards a phylogeny and definition of species at the molecular level within the genus $M y$ cobacterium.

Int J Syst Bacteriol 40:323-330 (1990).

8. Woese CR. Bacterial evolution. Microbiol Rev 51:221-271 (1987).

9. Gray MW, Sankoff D, Cedargreen RJ. On the evolutionary descent of organisms and organelles: a global phylogeny based on a highly conserved core structure in small subunit ribosomal RNA. Nucl Acids Res 12:58375852 (1984). 


\title{
感染マウスより分離した抗酸菌 HI-75 のゲノム解析
}

\author{
阪井哲男 ${ }^{1 ） * \quad ハ ミ ッ ト ・ ス テ ゙ イ ッ ク ~ 2) ~}$ \\ 松尾英一2）早川るり子1）脇坂 晟 ${ }^{1)}$ \\ 1) 杏林大学医学部第二生化学教室 \\ 2) 同 第一病理学教室
}

〔受付：1997 年 11 月 5 日/受理：1997 年 12 月 15 日〕

キーワード：抗酸菌 HI-75：DNA シークエンス：16S リボゾーム RNA：

ハンセン病：Mycobacterium scrofulaceum

Skinsnes らによって、らい腫より分離培養された抗酸菌 HI-75は、16Sリボゾーム RNAのダイレク トシークエンスの結果、Mycobacterium scrofulaceumに最も近似していたことを報告した。今回、さ らに抗酸菌 HI-75 をヌードマウスに接種し、感染巣の皮㲊結節より同菌を採取し、同様の方法でゲノム

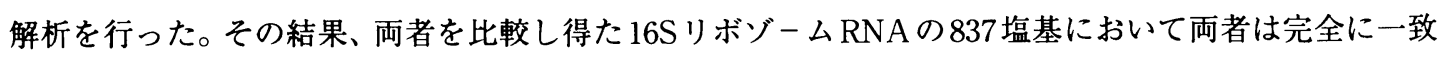
していた。抗酸菌 HI-75はM. scrofulaceumのヴァリアントとすれば、M. scrofulaceumも末梢神経に浸 潤し、神経病変を惹起させる可能性が示唆された。

"Corresponding author :

干 181 東京都三鷹市新川 6-20-2

杏林大学医学部

Tel: 0422-47-5511 Fax: 0422-40-7281 